\title{
Grass-ROOTS COMMEMORATIONS: REMEMBERING THE LAND IN THE CAMPS OF Lebanon
}

\author{
LALEH KHALILI
}

The Oslo negotiations-and the specter of a Palestinian renunciation of the right of return-greatly increased the insecurities of Palestinian refugees in Lebanon. The new uncertainties in turn triggered the emergence in the refugee camps of commemorative practices different from those previously sponsored by the Palestinian leadership. The new forms of commemoration, centered on the villages left behind in Palestine in 1948 and including popular ethnographies, memory museums, naming practices, and history-telling using new technologies, have become implicit vehicles of opposition and a means of asserting the refugees' membership in the Palestinian polity. Beyond reflecting nostalgia for a lost world, the practices have become the basis of the political identity of the younger generations and the motivation for their political mobilization.

COMMEMORATIVE EVENTS, whether organized by states or at the grass-roots level, almost always have a political dimension, though the forms of commemoration inevitably differ and the agendas may not be the same. The post-1948 Palestinian presence in Lebanon, where the commemorative events sponsored by the Palestinian protostate institutions were drastically reduced after the withdrawal of the Palestine Liberation Organization (PLO) in 1982 while grass-roots practices in the refugee camps continued, provides rich ground for looking at these differences and their significance.

In this essay, against macrohistorical events and elite politics, I foreground the mnemonic practices of politically and economically dispossessed refugees, using their narratives and practices-"the small voice of history" in Ranajit Guha's evocative phrase ${ }^{1}$ - to illuminate the ways in which they influence and are influenced by elite politics. To this end, I combine personal interviews and field research in Lebanon (where I lived and conducted research in the Burj al-Barajneh refugee camp) with an examination of memoirs, factional publications, and refugee texts.

Until the PLO was expelled from Lebanon in the wake of the 1982 Israeli invasion, there was no distinction between official/nationalist and "grass-roots"

\footnotetext{
LALeH KHALIu is a Ph.D. candidate in political science at Columbia University. She would like to thank John Chalcraft, Diana Allan, Muhammad Ali Khalidi, Ian Lustick, Shira Robinson, and the anonymous reviewers of the Journal of Palestine Studies for their comments on the text.
} 
commemorations, since political mobilization-in which mnemonic practices play a key role-centered on the refugee camps themselves. With the end of official sponsorship, however, the refugees continued their own commemorations, but in different forms. Because most Palestinian refugees in Lebanon's camps trace their origins to rural Palestine, their mnemonic practices focus on the remembered villages. Thus, whereas the officially sponsored commemoration had emphasized the master narrative and the macrohistorical, focusing on important dates in the history of the Palestinian struggle and celebrating "the homeland" as an abstract national ideal, the "grass-roots" practices center on the specific land on which the refugees-or their progenitors-had lived and worked. And whereas the nationalist/elite commemorative forms celebrated a united and harmonious-even homogenous-peoplehood, the popular mnemonic practices of the refugees emphasize local

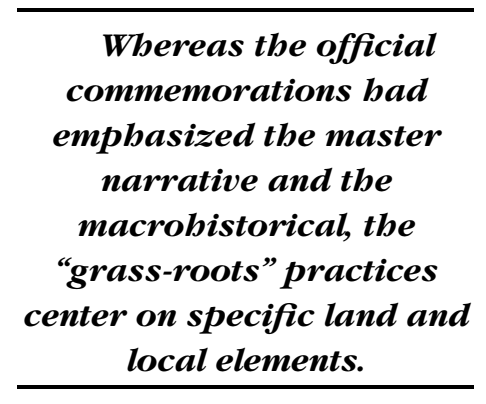
elements of collective memories and identities that the unifying narrative of the parastatal organizations tended to erase. ${ }^{2}$

These approaches have different political implications, but it was only in the early 1990s, when the goals and aspirations of the now-exiled national leadership and of the refugees in Lebanon began clearly to diverge, that refugee commemorations acquired oppositional overtones. As the asymmetrical peace negotiations between the PLO and Israel progressed, refugees increasingly feared that recognition of their rights-among them the right of return-would be "traded" for some kind of state in the occupied territories. This being the case, the commemorative practices in the camps have become public performances in which the refugees self-consciously reaffirm the legitimacy of their demand for inclusion in the national polity on the basis of their belonging to the subnational community. By placing the village at the heart of the nation, the localism of the grass-roots commemorative practices-which invoke the village in family histories, popular ethnographies, and spoken narratives-challenges the refugees' post-Oslo political marginalization. To insist on the trope of intergenerational transmission of memory-even if now the primary medium of transmission is the Internet or television-is another way in which the refugees insist that memory legitimates their belonging to the nation. Indeed, the tension between the modes of elite and popular commemoration shows that mnemonic practices are themselves the domain of contestation and resistance; not only does the refugees' commemorations of Palestinian life on the land as it was before 1948 challenge the leadership's "ownership" of Palestinian memories and its claim unilaterally to "represent" them, it also constitutes a critique of that which they consider unjust. ${ }^{3}$

\section{Official and Institutional Commemorative Practices}

States often expend massive resources on national(ist) commemorations. They build monuments, organize ceremonies, and produce school textbooks, 
political pamphlets, television programs, and tourist brochures aimed at promoting the national narrative. The PLO functioned very much like a state in Lebanon from the late 1960s until its ouster from Beirut in 1982, with protostate institutions administering the affairs of the Palestinians in exile even as the struggle continued for the establishment of a state in some part of Mandate Palestine. During this period-called the thawra, or revolution, by Palestinians - the PLO filled its official calendar with an array of nationalist rituals: almost-weekly festivals, street rallies, factional gatherings, theatrical performances, and speeches that were well advertised, well attended, and well reported. ${ }^{4}$ Special days commemorated key historical events: the issuance of the Balfour Declaration, the UN Partition Plan, the Nakba, Fatah's first military operation, the Battle of Karameh, Black September, and various other massacres and battles. There was also a Martyrs' Day ${ }^{5}$ and, as of 1977, Land Day. ${ }^{6}$ Less frequently, the PLO-specifically its Bureau of Affairs of the Families of Martyrs-commissioned monuments to massacres and national martyrs, such as small memorials to Tal al-Za'atar and Sabra and Shatila massacres in the Martyrs' Cemetery near the Shatila camp in Beirut. $^{7}$

Commemoration of Palestinian village life, on the other hand, was highly abstract, even on the part of those Palestinian factions that ostensibly spoke for the "workers and peasants." For example, articles about villages in al-Hadaf, the factional organ of the Popular Front for the Liberation of Palestine (PFLP), were not about Palestinian villages but about such topics as precapitalist modes of production and peasant life in Vietnam. The journals of the PLO Research Center published a handful of memoirs of the 1948 exodus during the 1970s, but these were mostly written by urban and urbane Palestinians living in Arab or European capitals. ${ }^{8}$ When, in the late 1990s, the Arab Resource Center for Popular Arts (ARCPA) undertook an oral history project in the camps, elderly Palestinians greeted the interviewers with the question, "where have you been all these years?" and complained that "the political organizations and leaders before you should have paid some attention."

During the thawra period, scholars who were engaged in oral history research were unable to get institutional support. ${ }^{10}$ According to one scholar, Palestinian research institutions-and even PLO activists- "weren't convinced that [oral history] research could help the national struggle, or the aims of their tanzim." 11 An additional factor may have been the potential for local testimonies to reveal lines of fracture-whether political or social-in the nation, betrayals by notables, or the existence of collaborators. ${ }^{12}$ The lack of interest in the more textured histories of smaller locales, however, did not prevent the protostate Palestinian institutions from commemorating an Arcadian Palestinian past in symbol-laden images or in detailed maps of Palestine showing the hundreds of destroyed villages. ${ }^{13}$ PLO posters and postcards from the mid-1970s are brimming with references to orange groves, wheat and olive harvests, keys to lost houses, picturesque village architecture, and traditional dress. ${ }^{14}$ Many of these references were adopted from the literary works of national writers such 
as Ghassan Kanafani, who were sensitive to the cultural signifiers of Palestinian village life and keen to record them.

The PLO-sponsored commemorative events for all practical purposes ended in 1982. And though the factions that remained in the camps continued to commemorate some national days, there was a noticeable decline in the number and scale of these events as factional resources dwindled further after the end of the civil war. Today, most national days are commemorated on posters rather than through actual gatherings, and the festivals held are jointly sponsored by NGOs and the factions pooling their resources. There has also been a marked change in the constituencies of the commemorative activities: whereas in the past they had been held in all Lebanon's main cities and attended not only by Palestinians but by Lebanese of all social classes, including leading political figures, ${ }^{15}$ today they are mostly all-Palestinian affairs held inside the camps or explicitly Palestinian spaces.

Meanwhile, after the PLO in its new exile in Tunis formally recognized the two-state solution in 1988, preoccupation with what had been lost in what is now Israel took a backseat to diplomatic maneuvering and an increased focus on the occupied territories (especially with the outbreak of the first intifada). In response, the rejectionist factions stepped up their emphasis on the lost Palestinian villages. Particularly after the Oslo agreement in 1993, rejectionist periodicals began to feature sections on pre-1948 village life (with such titles as "Lest We Forget"), and their political rallies in the camps and elsewhere forcefully reaffirmed the refugees' ties to the land as a source of dignity and human rights. ${ }^{16}$ There were still no oral histories to speak of, however, and the rejectionist emphasis on the rural past seemed less an expression of true identification with the village than a critique of the Fatah mainstream. Similarly, the Islamist groups then on the rise paid less attention to the concrete life stories of Palestinian villagers than to the importance of the land of Palestine as a sacred Muslim trust and favored the same abstract language in their press organs that secular nationalist organizations had used in their heyday. Concrete and detailed popular memories of life on the land were thus mostly absent from either nationalist or Islamist writings.

\section{Revival of Practices}

Mnemonic practices of Palestinians-as of other peoples-appear to increase in intensity when the livelihood or indeed the survival of the community is threatened. Since 1982, the Palestinian refugees in Lebanon have been without a unified local leadership capable of mobilizing a constituency or making political and social claims on their behalf. Moreover, local pressures have resulted in a series of Lebanese decrees and laws that have progressively deprived them of the most basic rights and protections guaranteed citizens even of authoritarian states. Blame for the civil war has been placed squarely on their shoulders, and the Lebanese government's increasingly adamant insistence on the Palestinian right of return seems transparently to express 
not support for refugee claims but the desire to evict them from Lebanon altogether.

Nonetheless, commemorative practices in the camps gained momentum especially as of the early 1990s. This is not accidental, since it was starting with the peace process, and the national leadership's "testing the waters" about giving up the right of return, that the refugee sense of having been abandoned by the leadership became acute. As lines of fracture emerged in the cross-border body of the Palestinian polity, attachments to both subnational (such as village, camp, and kinship networks) and supranational (such as Islamism) forms of community and identification have grown. ${ }^{17}$ In such a context, commemorations of village life are reflexively and consciously reproduced as "collective claims to a land title grounded in suffering ancestry." 18

More recently, several almost simultaneous developments have reaffirmed the Palestinian refugees' emplacement within the national territorial imaginary. First and foremost, Israel's military withdrawal in May 2000 from southern Lebanon, occupied since 1982, allowed reconnections with the landscape of Palestine as well as with relatives on the Israeli side of the border. Within days of the withdrawal, refugees were streaming to the border zone to "see with their own eyes" the Galilee left behind by their parents or grandparents. These pilgrimages were initially organized by the political factions or the NGOs in the camps, which bused the refugees to the border. The organized tours were soon followed by independent trips, where families or groups of friends would arrive in private cars or inexpensive "service" (group) taxis to spend a spring or summer day picnicking in the fields or holding shouted conversations across the border fence and "no-man's-land" with long-lost relatives now Palestinian citizens of Israel. ${ }^{19}$ Many of the young people I talked to in Burj al-Barajneh told of emotional visits to the Fatima Gate or climbing the Israeli-built watchtower where they wept to see the land of Palestine. Such border visits continued without constraint for several months, until Hizballah consolidated its control over the area. Thereafter, visits were possible only with permission from Hizballah, which itself bused refugees to the border zone-henceforth a site of political expression-for planned demonstrations.

The second development was the outbreak of the al-Aqsa intifada four months after the Israeli withdrawal. By effectively ending the Oslo process, the new uprising gave the refugees hope that the expected "deal" trading the right of return for statehood would not be consummated. Camp residents remained glued to the satellite news channels, endlessly debating how the events in the territories would affect their fate; the almost constant footage of Palestinian locales on the news further sharpened interest in the homeland. In order to make their voice-and their support of the intifada-heard, they held solidarity demonstrations and vigils in the camps, in Lebanese towns, and in the border area, albeit under the cover of Lebanese-sponsored demonstrations or in coordination with Lebanese political organizations (notably Hizballah). During one of these demonstrations, on 7 October 2000, two young refugees, Shadi Anas of Burj al-Barajneh camp and Hasan Hasanayn of Shatila, were shot 
dead by Israeli soldiers. A sixteen-year-old neighbor of Anas (who later chose MA[rtyr]Shadi2000 as her email handle) told me that in her mind "Martyr Shadi had become part of the Palestinian soil." Thus, two important nationalist tropes, martyrdom/resistance and "the homeland," were conjoined in these cross-border demonstrations.

Finally, the Internet explosion in refugee camps and the proliferation of cyber-connections between Palestinian youth across national boundaries have strengthened a national identity that is politically (rather than geographically) defined, emphasizing the transnational character of this identity. ${ }^{20}$ The infrastructure for such connections is provided by the transnational Palestinian NGO Across Borders Project, whose centers in Burj al-Shamali and Nahr al-Barid camps in Lebanon not only provide camp residents with Internet access, but also maintain ongoing links with their cohorts in the occupied territories. ${ }^{21}$ In other camps in Lebanon where dedicated NGO resources for such Web centers are not available, Internet-savvy youth have found alternative means of cyber-communication with their peers in the occupied territories such as chatrooms, PalTalk, ${ }^{22}$ and Instant Messenger. ${ }^{23}$ Among the most popular digital files exchanged across borders are images of places in Palestine and Israel; the camp's young people receive photographs-both current and of pre-1948 Palestine-over the Internet and send them to all their friends, thus disseminating their "memories" of Palestine.

\section{Villages Mapped Upon the Camps}

Place of origin has always figured prominently as a marker of identity among Palestinians, concretizing connections to specific locales. It has long been noted that Palestinians meeting for the first time ask where the other is from, and identify third parties in the same way. Specific accents and characteristics are sometimes associated with particular villages, ${ }^{24}$ and tombstones even of refugees born in Lebanese camps identify the deceased by the family village in Palestine.

Indeed, Palestinian village life is commemorated in the very geography of Lebanon's refugee camps: when the camps were first established, the refugees gathered in groups that replicated their village and family ties, with the result that the various camp quarters were named for Palestinian villages. ${ }^{25}$ In such a way did the entire camp become a mnemonic marker for village life. Since those early years, the cramped spaces of Lebanon's refugee camps have undergone significant changes in cartographic notation. During the 1970s, the heyday of Palestinian factional control, village names of the quarters were changed to reflect the political organizations that held sway there: "Iqleem Fateh," "Iqleem Dimokratiyyeh [DFLP]," the "Maktab Siyasi [PFLP]" and so on. ${ }^{26}$ Interestingly, however, after the expulsion of the national leadership in 1982, and especially with the postwar reconstruction of the camps in the 1990s, the old village designations reappeared-the Tarshiha quarter of Burj al-Barajneh camp, for example, renamed the PFLP quarter during the thawra, once again became 
the Tarshiha quarter. Given that the original concentration of refugees from particular villages has been diluted over time, as descendants of the original residents have moved away for marriage or work or during periods of hostilities, the revival of village designations indicates both the durability of the original connections and a conscious effort by camp residents to maintain the link with specific places in Palestine. ${ }^{27}$

On the institutional level, village notables have continued to wield influence in camp affairs despite the substantial social transformations in the camps over the past fifty years. In the early years, they had played a preponderant, if unofficial, role as intermediaries between the refugees and the authorities in addition to assuring a kind of "social control." Though their role was greatly downgraded during the thawra period, when PLO institutions ran the affairs of the camps, they continued to have some importance as mediators among the various factions and as a restraining influence on armed youth. ${ }^{28}$

Significantly, the deteriorating conditions after 1982 led to a revived emphasis on the pre-1948 village ties, with the camp residents organizing "village committees" to mitigate the loss of security and the erosion of their civil rights. The village committees do not play a direct political role-in principle, the camps continue to be run by popular committees made up of the political factions-but they do provide their members with financial and other assistance (e.g. for funerals, weddings, education ${ }^{29}$ ). Among the villages that have spawned committees are al-Nahr, Dayr al-Qasi, 'Alma, Suhmata, Qaditha, al-Suwayalat, and Bassa. ${ }^{30}$ In the Burj al-Barajneh camp, I am aware of the Kabri, Tarshiha, and Kwaykat committees, among others. Since natives of different villages are concentrated in particular camps (e.g. 'Alma in Nahr al-Barid, Kwaykat and Tarshiha in Burj al-Barajneh), the committee for a given village is usually present in only one camp, though it may provide assistance to relatives living in others. The committees tend to operate informally, without elections or by-laws, and are more like councils of elders. The communally recognized elders of Tarshiha in Burj al-Barajneh, for example, meet informally over tea or coffee to exchange reminiscences and to discuss the practical affairs of the camp, especially the distribution of funds. Information about needs generally comes through the "grapevine," which operates through village-centered familial and friendship networks, marriage, and kinship ties. The work of the village committees complements that of the NGOs in trying to alleviate economic hardships, while at the same time strengthening connections to the villages that could otherwise be diluted through marriage or dispersion.

\section{Grass-roots Commemorative Practices AND NARRATIVES}

As noted above, the rural origins of the vast majority of the Palestinians in Lebanese camps, and the symbolic importance of these rural origins in nationalist semiotics, ${ }^{31}$ make it inevitable that the village-and land-would be at the very heart of refugee commemorative practices. The fact that the collection 
of village artifacts, the compilation of village books, and the assembling of mnemonic narratives (for example, by ARCPA) that constitute these practices have proliferated after a relative political lull following the 1993 Oslo agreement attests to the constitutive role of concrete village connections in these endeavors. At the same time, the oppositional dimension of grass-roots commemoration is aided by new and decentralized forms of "print capitalism,"32 such as self-publishing or the Internet, and by the rising importance of electronic media (especially satellite television). These new phenomena have encouraged decentralized mnemonic practices and, even more so, the emergence of national "fragments."33

\section{Names and Symbols}

Susan Slyomovics has written evocatively about Palestinian daughters being named after lost villages, ${ }^{34}$ and this practice occurs in the refugee camps as well; Palestinian girls thus become the literal embodiment of remembered places. A far newer phenomenon is the way many Palestinian youths incorporate the names of their parents' or grandparents' villages in their Internet and email monikers-examples (modified for the purposes of anonymity) would be SAFFURIEH2001@aaa.com commemorating the destroyed village of Saffurieh in Galilee, or WALID_FARA@aaa.com combining a young man's first name with the name of his grandfather's village in Safad district. Similarly, the number forty-eight appears again and again in Palestinian cyber-monikers; the year of exile is thus evoked with each email sent. In this way, refugees appropriate new technologies to reinvigorate their commemorative practices.

Probably the most common commemorative symbol is the key to the house left behind in 1948, the house to which the family had expected to return as soon as the fighting died down. But while the key has always been an important Palestinian national symbol, its proliferation in recent years is significant. While visiting homes in the camps, I noted that even those families who no longer had the original key (often lost in the multiple displacements of the civil war) would have mass-produced reproduction keys prominently displayed, often next to an image of the Dome of the Rock. Though some families have large rusted iron rings laden with multiple keys (to storerooms as well as courtyards and houses), it is the single key that dominates the popular imagination. In one of his short stories, Ghassan Kanafani wrote movingly about the "large, beautiful, somewhat strange key" that hung in the family home of the protagonist/narrator. "The winds of twenty years passed over it and dust had collected on it.... I remember that once when my sister took it down to clean the dust off it, the room immediately seemed incomplete and cold and forsaken." 35

The key not only adorns houses, but is worn prominently at demonstrations, pictured on right of return posters, and digitized in cyber-circulars. It is often the first thing camp families show to foreign visitors. When refugee children are asked in after-school programs to draw images from their lives, they often incorporate a key in their drawings. The key's hold on the popular imagination undoubtedly derives from its concreteness as a symbol and 
the way it incorporates the past, present, and future in a coherent existential narrative. Thus, a single semiotically rich object embodies forced expulsion, the expectation of return, and the tangibility of refugee claims. This popular "singularisation" 36 of an ordinary object takes it beyond the daily context of usage; imbues it with meaning, memory, and history; and transforms it into a symbolically laden manifestation of political ideas and claims.

\section{The Recreation and Preservation of Village-Related Objects}

There is probably not a house, however small and poor, in a refugee camp in Lebanon where images of Palestine are not prominently displayed. Pictures and drawings of the Dome of the Rock almost always dominate sitting rooms. In recent years, families in the camps have begun actively seeking village-related objects as well. Deeds to lands left behind and identity cards issued by the Mandate authorities are now actively sought from family elders and readilythough carefully-shown. Pre-1948 maps are also popular, as are images of the village as it may have been or even as it is today. When a man originally from Tarshiha, now a citizen of Norway, made a videotape of his home village now in Israel, ${ }^{37}$ he sent copies to relatives in Syrian and Lebanese camps who in turn made additional copies and distributed them. At the time of my fieldwork, this meandering amateur videotape of Tarshiha's streets had pride of place in many houses, most of which did not even have videoplayers.

A particularly well-developed example of popular efforts to document Palestinian village life is the memory museum built by Mahmud Dakwar in 1991 . Located in his small house near Burj al-Shamali camp in Tyre, the museum "presents in the name of Palestine and not under the title of a person, a party, or an organisation" a collection of daily artefacts used by Palestinian villagers of Galilee before their diaspora. ${ }^{38}$ Dakwar started the museum, the only one of its kind in Lebanon, on his own initiative and with his own money, collecting textiles; coffee-making implements; glassware and pottery; agricultural, mining, and other tools; harness and riding gear; games; stones from various locations; title deeds; travel permits; petitions; wills; marriage and death certificates; and other objects in order "to document Palestinian collective memory in danger of disappearing and, along with it, national identity and heritage."39 For Dakwar, the preservation of objects embodying a people's heritage and history is an almost sacred duty. "I am not a man of weapons and guns," he says, "I understand the homeland through the logic of culture and civilisation.. ${ }^{40}$ Dakwar's elision between armed struggle and preservation of cultural heritage points to the claim-making content of commemoration. Dakwar, who emphasizes that he has no connection with any political faction, is well-known among Tyre's Palestinians and serves as the conduit between the local community and Beirut-based Palestinian NGOs involved in the preservation of pre-1948 folklore, narratives, and objects. ${ }^{41}$ Though the political organizations have neither supported nor shown any interest in Dakwar's work, his ethnographic museum is much visited, especially by Burj al-Shamali youth, attesting to the 
revitalized interest in Palestinian village life that has marked the post-Oslo era.

\section{Village Books}

Among the most significant grass-roots commemorative efforts by the Palestinian refugees in Lebanon has been the publication of "village books." Following the example of the monographs on specific villages put out by Birzeit University and the Dar al-Shajara as of the late $1980 \mathrm{~s},{ }^{42}$ the post-1948 generations have begun writing "popular" historical ethnographies of their lost villages. A number of these, including books on Dayr al-Qassi, 'Alma, al-Damun, and Kwaykat, ${ }^{43}$ have come out in recent years, published by the authors with their own savings. Intended strictly for local consumption, they are written solely in Arabic and are not available for sale outside the camps, being distributed by the authors through informal networks of family and friends or sold in camp grocery stores or by word of mouth. Though the books have only one or two authors, they could not have been written without major input from the older generations. Indeed, it is not coincidence that the books that have come out have been about villages with active committees in the camps; the gathering of elders is often the most useful forum for the ethnographic work needed to produce them.

The books range from 200 to 300 pages and follow similar formats, apparently modeled after the Birzeit or Dar al-Shajara publications. All have chapters or sections devoted to the village's history and geographical setting, detailed listings of the pre-1948 village families or heads of households (including their land holdings and occupations), and detailed ethnographies of village customs. They also include photographs of the village (or its ruins) taken after 1948, historical photos from published sources, personal photos of family members, reproductions of pre-1948 documents (e.g., identity cards, title deeds), and "memory maps" of the village (in fact more like diagrams) drawn up with the help of village elders. And although the popular village books borrow elements from scholarly works on the villages-for example, the sections devoted to the village's physical and geographic characteristics are often reproduced from Walid Khalidi's All That Remains-the authorship is decidedly local, drawing mainly on the memories of the villagers.

The Kwaykat volume, produced in Burj al-Barajneh, is fairly typical. It includes eight chapters: on the geography and history of the village, the families of the village, social life, the village economy, local customs, common sayings, and finally the author's account of his visit to the ruined village in 2000 . A wealth of information is provided: the qualities needed for the mukhtar and other village notables and what their duties were; daily activities - prayer at the mosque; schooling, men's gatherings in coffeehouses; the role of women; food preparation and meals; medicine and healing practices; old style and modern houses and their furnishings; dress; remembered events such as the introduction of the first radio to the village in 1943; crops, livestock, and farming practices; what trades were practiced; means of transport and communications; and how 
the villagers celebrated the religious holidays, Ramadan, as well as weddings, funerals, wakes, births, circumcisions, the return from the Hajj, and so on. The section on the fall of the village in 1948 includes oral testimonies by village elders describing the circumstances of their eviction as well as their wanderings from village to village until their eventual settlement in the camp. The other village books follow similar outlines, though the material covered is not always exactly the same: the 'Alma and Dayr al-Qasi volumes, for example, also document pre-1948 relations between their respective villages and their neighbors (including Jewish settlements).

The exacting detail and obsessive concern for accuracy evident in all the books is striking-the exhaustive listing of names (not only of families, but also, for example, of those who served with the

The writing of the village books was motivated by a sense of accelerating loss, not only of the land itself but also its memory, as the older generations die off.
Ottomans in World War I, the martyrs of the 1936-39 revolt and the 1948 war, who owned land and how much, who grew what kind of trees, who practiced what trade); the precise kinds of crops grown (the price of 100 oranges in 1948 is documented as 5 qrush); transcriptions of folk poetry celebrating the harvest and specific crops; which Quranic verses are read and which songs are sung at what occasions; the correct greetings and sayings in various social situations; how exactly certain foods are prepared; and so on. Propelling all the authors was the notion that whatever is not written down will be lost.

Indeed, the writing of the books was motivated by a sense of accelerating loss, not only of the land itself but also its memory, as the older generations die off. Ibrahim Uthman, the author of the Dayr al-Qassi volume, mentions the "race against time" in gathering the minutiae of village history before it is lost. "Some [of the elders] passed away a few days after the interview," he explained, "and others died before I had a chance to reach them.. ${ }^{44}$ The multiple displacements and tragic violence experienced by the Palestinians in Lebanon no doubt heighten the sense of urgency to salvage memories, identity markers, and claims to the land before some new disaster befalls the community. The misery of their current situation also plays a role: the perception of how things are now motivates the authors to record and document how things were then. And beyond their desire to salvage the past for its own sake is the explicitly stated determination to leave a legacy for future generations. Uthman speaks about setting aside fifty copies of the book for his descendants, while Abdalmajid al-Ali, the author of the Kwaykat volume, says that he writes "so that the [future] generations wouldn't forget this village and our heritage, our customs, and our habits and our sayings, and the methods of farming and construction and commerce and everything else. ${ }^{25}$ Already the youth pore over family names, tracing relations of current camp neighbours and friends, as well as details of village crafts, agriculture, and businesses.

More than an act of salvage ethnography, the village books represent an act of political advocacy: all the books include what are in effect advocacy texts and images. Ali's book includes photographs of the Dayr Yassin massacre, 
not only because photographs of the Kwaykat massacre were not available but because of Dayr Yassin's national(ist) significance. Similarly, he includes photographs of the shouted cross-border meetings between relatives after the Israeli withdrawal, in order to reaffirm, in Ali's words, the "unity" of Palestinians across borders. The authors of the "Alma volume began compiling their work to protest the "resettlement" options being discussed in the late 1990s and see the task of documenting the history of the defeated as a necessary step in the "war against the colonisers." ${ }^{46}$ Uthman writes in the Dayr al-Qassi volume that history and blood will defeat "the sword," so that the history of every tree needs to be documented ${ }^{47}$ Husayn Ali Lubani, the author of the Damun volume, includes a six-page passage on the right of return, declaring that the act of recording land ownership in Damun in effect reaffirms refugee claims to their lost villages. ${ }^{48}$

\section{Remembering Fruit Trees}

Narrative commemoration of preexilic life, especially when part of a strategic effort to reinforce national identities across generations,${ }^{49}$ is an important component of Palestinian mnemonic practices. Today, some of the primary media through which these narratives are promulgated are television and radio programs. Al-Manar's television series al-Aidun and Yatazakkarun as well as radio series produced in Saida and Tyre all record stories told by Palestinian elders for the consumption of both Lebanese and Palestinian audiences. When Palestinians-even those who have never actually seen Palestine-tell their stories to their families or to a television audience, one of the most emphatic elements is the repeated references to plentiful orchards and rich water sources (springs, streams, and rivers). Trees and their rooting in national soil are particularly significant metaphors in a context of displacement, where exile, forced or voluntary, is often articulated as an "uprooting" 50 or as being "scattered like seeds." ${ }^{51}$ The scores of interviews I conducted with members of the older generation were full of detailed descriptions of specific landscapes with named springs and specific kinds of trees, a direct challenge to the Zionist narrative of "making the desert bloom" and of redeeming the "barren wasteland" the Arabs had made of the original "land of milk and honey." 52 The physical struggle over land between Zionists and Palestinians is thus extended to the rhetorical domain-to the stewardship and cultivation of the land.

A hierarchy of natural harvests likewise came through the interviews: while wild herbs are better than cultivated crops, both are far superior to "what you buy." Implicit in such narratives is both a critique of urbanization (where wild herbs cannot be picked) and a lament of dispossession (where one cannot produce one's own food and has to purchase it). It has become a cliché among Palestinians that no orange or fig or grape can taste as delicious as those picked off the vines and branches of Galilee; even the younger generation who never knew Palestine are convinced that the best trees and sweetest waters are found there. When I asked a man who had spent his life shuttling between a job in Saudi Arabia and his family in Burj al-Barajneh camp what he imagined Palestine 
to look like, he described a land "like paradise," all green and full of rivers and trees that made him "feel secure and comfortable." In the refugee's life of instability and impermanence, it is not surprising that cultivation and wellwatered lands should be associated with security and comfort; the imagined utopias are clearly less about the beauties and happiness of the past than specific and context-dependent critiques of how things are as well as a call for moral accounting.

In The Country and the City, Raymond Williams points out that evocations of a lost pastoral innocence "come[s] not from the lordly or the landless, but from the shifting intermediate groups" who had achieved "a place in the altering social structure of the land but [were] continually threatened with losing it" to become "the landless poor." ${ }^{53}$ Whether the refugees I interviewed had been sharecroppers or landowners (or remembered themselves as one or the other), they all considered themselves as having a right to the land on the basis of the expended sweat of their brow. Economically dispossessed by the Nakba, they had been transformed into what Giorgio Agamben calls homo sacer, with lives so politically worthless as to be utterly forsaken. ${ }^{54}$ Having been doubly dispossessed, of property and of political rights, and wrenched from stability to a permanent impermanence marked by squalid living conditions, the refugees rhapsodize about a land of plenty, implicitly contrasting it with the desperation of current conditions in which they are deprived not only of political community, social welfare, economic security, and civil rights, but even of simple human dignity and a guarantee of survival.

\section{BALAD: VilLAGE AND NATION}

Palestinian refugees in the camps of Lebanon commemorate their lost villages and their preexilic life in Galilee not as an act of nostalgia, but as a meaningful political activity inscribed in the organization of their daily lives, their identity, and their social institutions. The intensification in the last few years of the mnemonic practices represents a conscious effort at grass-roots mobilization as part of their political claim-making; indeed, in centering virtually all these practices on the lost villages, the refugees deliberately fuse the multiple meanings of the word balad, which can refer either to the village or the whole of Palestine. ${ }^{55}$ For them, to recount and commemorate their belonging to the village is a way of declaring membership in the nation, concretizing their belonging to the Palestinian polity in the face of possible exclusion from it. In this sense, the commemorative practices are forward-looking political acts intended by the refugees as critiques of their leadership and their current social and political predicament.

The refugees' insistence on territorializing their identity and tangibly locating their villages within the national(ist) cartography challenges the leadership's prevailing nationalist rhetoric that tends to erase or downplay the local and the quotidian. Yet at the same time, it also complements the nationalist metanarrative, fleshing out the national(ist) imagination with the details of 
local life even while invoking durable attachments to particular places that define and concretize the boundaries of the nation. The concrete imagining of Palestinian refugees furthermore speaks of the qualitative transformation in grass-roots national imagination, which has endowed the abstract framework of a harmonious nationalist rhetoric with details of daily lives, however idealized; in place of a grand national narrative, the textured life of ordinary villagers is celebrated. Furthermore, it details the ways in which the quality of Palestinian nationalist imagining has changed over time from symbolic abstractions to concrete articulations of belonging to a transnational polity, where the claim of rootedness in a particular village legitimates membership in the larger imagined identity.

Most important, as the generation that remembers living in Palestine passes away, commemorations of quotidian life in Palestine becomes for subsequent generations not merely a narrative or practice of remembering and reconstructing, but the basis of their political identity and the motivation for their political mobilization. Thus, rather than being emblematic of a timeless Palestinian nationalism or unchanging nostalgic memories, the refugees' commemorative practices emerge at a time where their political and social life is in grave danger of further dispersion and deterioration, and the narratives are reproduced and urgently asserted in order to serve the refugees' political purposes. Reaffirming attachments to the land and one's provenance in the lost villages becomes the refugees' way of participation in "the daily plebiscite" 56 that is the Palestinian national polity.

\section{NoTeS}

1. Ranajit Guha, "The Small Voice of History," in Subaltern Studies IX: Writings on South Asian History and Society, eds. Shahid Amin and Dipesh Chakrabarty (Delhi: Oxford University Press, 1996).

2. Certain intellectual ventures, such as Nazzal, as well as the Birzeit series of books, similarly emphasize local connections. Nafiz Nazzal, The Palestinian Exodus from Galilee, 1948 (Washington: The Institute for Palestine Studies, 1978).

3. On memory as a domain of moral judgement, see Ted Swedenburg, Memories of Revolt: The 1936-1939 Rebellion and the Palestinian National Past (Minneapolis: University of Minnesota Press, 1995); Richard Werbner, "Smoke from the Barrel of a Gun: Postwars of the Dead, Memory and Reinscription in Zimbabwe," in Memory and the Postcolony: African Anthropology and the Critique of Power, ed. Richard Werbner (London: Zed Books, 1998); Raymond Williams, The Country and the City (London: Hogarth Press, 1985).
4. See every January issue of Filastin al-Thawra between 1972 and 1982, in which photographs and extensive text accompany accounts of commemorations of the beginning of armed struggle on 1 January 1965.

5. Different factions had different Martyrs' Days. Fatah celebrated Martyr's Day on 10 April, the anniversary of the 1973 assassination of three Fatah leaders.

6. Land Day was celebrated on 30 March, the anniversary of the 1976 demonstrations in Nazareth to protest Israel's ongoing seizure of lands owned by its Palestinian citizens. In the course of the demonstration, Israeli police shot dead six Palestinians and wounded more than fifty.

7. It has also commissioned smaller monuments to martyrs in other cemeteries in Lebanon, most significantly in Ain al-Hilwa. See Laleh Khalili, "Places of Mourning and Memory: Palestinian Commemoration in the Refugee Camps of Lebanon," Comparative Studies of South 
Asia, Africa and the Middle East (forthcoming 2004).

8. See, for example, Muhammad Hisham al-'Azm, "Soqut Safad" (The Fall of Safad), Shu'un Filastinyah 33 (1974), pp. 122-32; Sir Geoffrey W. Furlonge, Palestine Is My Country: The Story of Musa Alami (New York: Praeger, 1969); Elias Shoufani, "The Fall of a Village," JPS 1, no. 4 (Summer 1972), pp. 108-21. A notable exception is Nazzal, The Palestinian Exodus from Galilee, 1948, which uses oral history and interviews with ordinary refugees to tell the history of Palestinian exodus.

9. ARCPA, "'This Illiterate

Woman... She Talked to Us': Participants' Responses to ARCPA's 1948 Uprooting Oral History Project," Al-Jana (May 1998), p. 43.

10. "I recall clearly that before the invasion of 1982, I and a number of comrades tried our hardest to convince leading academic institutions, any of which would have been able to start collecting oral history testimonies, even if only from certain camps or in a limited number. However, our attempts . . failed." Bayan Al-Hout, "Oral History: Continuous, Permanent Connection," Al-Jana (May 1998), p. 11

11. Rosemary Sayigh, "Oral History for Palestinians-the Beginning of a Discipline," Al-Jana (May 1998), p. 6.

12. See also Ted Swedenburg, Memories of Revolt.

13. See Ted Swedenburg, "The Palestinian Peasant as National Signifier," Antbropological Quarterly 63 (1990), pp. 18-30.

14. Many of these posters and postcards were reproduced from Palestinian paintings many of whose painters lived in Beirut. See Kamal Boullata, "Artists Re-member Palestine in Beirut," JPS 32, no. 4 (Summer 2003), pp. 22-38. On Palestinian posters during the thawra, see Shafiq Ridhwan, Al-mulsaq al-Filistini: Mashakel al-nishat wa al-tatawwar (Damascus: Da'eret al-Thaqafa, Munazzama al-Tahrir al-Filistini, 1992). See also the vast collection of Palestine posters of Dan Walsh at www.liberationgraphics.com.

15. The 1 January commemoration of Fatah's first military operation, for example, was held annually in the Municipal Stadium in Beirut with a great deal of fanfare.
16. Faisal Darraj, “'An 'Alaqat al-Ardh wa al-Watan wa al-Zakira," Al-Hadaf 1183 (3 April 1994), p. 9.

17. Randa Farah, "Reconstruction of Palestinian Identities in al-Baq'a Camp," in Palestine, Palestiniens: Territoire

National, Espaces Communautaires, eds. Riccardo Bocco, Blandine Destremau, and Jean Honnoyer (Beirut: CERMOC, 1997), p. 262.

18. Jonathan Boyarin, Palestine and Jewish History: Criticism at the Borders of Ethnography (Minneapolis: University of Minnesota Press, 1996), p. 8.

19. For a record of such visits, see Mai Masri's 2001 documentary, Ablam al-Manfa (Dreams of Exile, which was renamed Frontiers of Fears and Dreams for its European and American releases).

20. See my forthcoming article on Palestinian cyberculture in the camps of Lebanon, "Virtual Nation: Palestinian Cyberculture in Lebanese Camps," in Palestine/Israel and the Politics of Popular Culture, eds. Rebecca L. Stein and Ted Swedenburg (Durham: Duke University Press, forthcoming 2004).

21. The Across Borders Project centers in the occupied territories are in Dahaysha, Jalazone, and Amari camps in the West Bank, and Khan Younis camp in Gaza.

22. PalTalk (whose name is not derived from "Palestine") is a public forum that provides debate platforms, where officials invited by NGOs or activist organizations can respond to public questioning.

23. Such connections were developed between the children of Shatila and Dahaysha camps and is documented in Masri, Ablam al-Manfa.

24. Rebecca Roberts, Bourj al Barajneb: The Significance of Village Origin in a Palestinian Refugee Camp (MA diss., University of Durham, 1999).

25. Hallah Ghazzawi, "La mémoire du village et la préservation de l'identité Palestinienne," in Palestine: Mémoire et Territoires, eds. A. Mahmud Abdulaziz, Hallah Ghazzawi, Alain Joxe, Camille Mansour, and Elias Sanbar (Paris: École Des Hautes Études En Sciences Socialies; Cahiers D'Études Stratégiques No. 14, 1989), p. 36.

26. Rosemary Sayigh, Too Many Enemies: The Palestinian Experience in Lebanon (London: Zed Books, 1994), p. 92. 


\section{Rebecca Roberts, Bourj al} Barajneh.

28. Sayigh, Too Many Enemies, pp. 98-99.

29. Jaber Suleiman, "The Current Political, Organizational, and Security Situation in the Palestinian Refugee Camps of Lebanon," JPS 29, no. 1 (Autumn 1999), p. 75 .

30. Ibid.

31. Swedenburg, "The Palestinian Peasant."

32. Benedict Anderson, Imagined Communities: Reflections on the Origin and Spread of Nationalism (London: Verso, 1991).

33. Partha Chatterjee, The Nation and Its Fragments (Princeton: Princeton University Press, 1993). I am grateful to Muhammad Ali Khalidi for pointing out the importance of new forms of print capitalism.

34. Susan Slyomovics, The Objects of Memory: Arab and Jew Narrate the Palestinian Village (Philadelphia: University of Pennsylvania Press, 1998), pp. 201-203.

35. Ghassan Kanafani, "The Child Discovers that the Key Looks Like an Axe," in Palestine's Children: Returning to Haifa and Other Stories, translated by Barbara Harlow and Karen E. Riley (Boulder: Lynne Rienner, 2000 [1967]), p. 111.

36. Alan Radley, "Artefacts, Memory and a Sense of the Past," in Collective Remembering, eds. David Middleton and Derek Edwards (London: Sage Publications, 1990), pp. 52-53.

37. Tarshiha is one of the villages that was not destroyed and continues to be inhabited by Palestinians. Many Tarshihans in Lebanon express pride that Azmi Bishara, an Arab member of the Israeli Knesset, is from their village.

38. Jabir Abu Hawash, "Majmu'a Mahmud Dakwar Turathiyya: Mathaf ithnogirafi lil-Zakira al-Filistiniyaa," Al-Jana 5 (1997), p. 15.

39. Ibid., 17

40. Ibid.

41. Although most Palestinian NGOs have at one time or another allocated resources to the collection of pre-1948 life stories, the aforementioned ARCPA is the most prominent NGO devoted solely to cultural activities among the Palestinians.

42. The Center for Documentation and Research at Birzeit University in Ramallah published two series of village books on twenty-one villages between 1987 and 1997. The Dar al-Shajara series, published in Damascus, includes at least six books. There are other village books, published mostly in the occupied territories by independent scholars and researchers, but these are not easily available in Lebanon. See ARCPA, "Bibliography," Al-Jana (2002), pp. 68-69.

43. These were the only village books I was able to secure during my fieldwork; others were distributed informally through word-of-mouth and thus are difficult to obtain. The aforementioned books are as follows: Ahmad Atiya and Hasan Atiya, Alma: Zaytuna Bilad Safad (Beirut: n.p., 1998); Ibrahim Khalil 'Uthman, Dayr al-Qasi: Zanbaqa al-Jalil al-Awsat al-Gharbi (Beirut: n.p., 2000); Husayn Ali Lubani (Al-Damuni), Al-Damun: Qariya Filistiniyya fi al-Bal (Beirut: Dar al-Arabi, 1999); and Al-Haj 'Abd al-Majid al-'Ali, Kwaykat: Abad Sharayin Filastin (Beirut: n.p., 2001). The Atiya brothers and Lubani live in Nahr al-Barid. Uthman and al-Ali are residents of Burj al-Shamali and Burj al-Barajneh camps respectively.

44. Reem Haddad, "Labor of Love Produces History of Lost Village," Daily Star, 10 May 2001.

45. Interview with author, Burj al-Barajneh, 9 March 2002.

46. Atiya and Atiya, Alma, p. 10.

47. Uthman, Dayr al-Qasi, p. 218

48. Lubani, Al-Damun, p. 255.

49. Passing on the narratives of preexilic life is an important Palestinian commemorative trope. Many of the refugees I interviewed insisted that they deliberately passed on their stories to their children and grandchildren as a means of preserving the Palestinian identity.

50. Carol Bardenstein, "Trees, Forests, and the Shaping of Palestinian and Israeli Collective Memory," in Acts of Memory: Cultural Recall in the Present, eds. Mieke Bal, Jonathan Crewe, and Leo Spitzer (Hanover: Dartmouth College, 1999), pp. 148-68; and Lisa Malkki, "National Geographic: The Rooting of Peoples and the Territorialization of National Identity among Scholars and Refugees," Cultural Anthropology 7 (1992), pp. 24-44.

51. The appearance of roots, plants, trees, and seeds (not to mention land) in titles and contents of Palestinian books, stories, essays, poetry, and songs is 
frequent and widespread. See, for example, Shaw J. Dallal, Scattered Like Seeds, Sahar Khalifeh, Wild Thorns, Ghassan Kanafani, "The Land of Sad Oranges," Sahar Khalifeh, 'Abbad al-Shams (Sunflowers), Liyana Badr, "A Land of Rock and Thyme," and countless others. For an examination of the importance of trees in Palestinian poetry and its symbolic importance in Palestinian protests in the occupied territories, see Bardenstein, "Trees, Forests," pp. 148-57.

52. Boyarin, Palestine, p. 62 ;

Bardenstein, "Trees, Forests," p. 161.

53. Williams, The Country and the City, p. 43.

54. Giorgio Agamben, Homo Sacer: Sovereign Power and Bare Life, translated by Daniel Heller-Roazen (Stanford: Stanford University Press, 1998).

55. The conflation of the village and the homeland is not limited to Palestinian refugees, villagers, or nationalists. Eric Hobsbawm notes that paese ("country") in Italian and pueblo ("people") in Spanish can mean either a village or the national territory or its inhabitants. He further notes that nationalism and the state "took over the associations of kin, neighbours and home ground." Eric Hobsbawm, The Age of Empire: 1875-1914 (London: Weidenfeld and Nicolson, 1987), p. 148.

56. Ernest Renan, "What Is a Nation?" in Nation and Narration, ed. Homi K. Bhabha (New York: Routledge, 1990), p. 19. 